NATALIA KOHTAMÄKI ${ }^{1}$

Uniwersytet Kardynała Stefana Wyszyńskiego

\title{
KULTURA ORGANIZACYJNA W AGENCJACH REGULACYJNYCH UNII EUROPEJSKIEJ²
}

Słowa kluczowe: kultura organizacyjna, agencje regulacyjne, Komisja Europejska, administracja publiczna, zarządzanie międzyrządowe

Keywords: organizational culture, regulatory agencies, European Commission, public administration, intergovernmental governance

\section{WPROWADZENIE}

- uropejska przestrzeń administracyjna ulegała w ostatnich latach daleko idącym przemianom. Ważną rolę $w$ procesach tych zmian polegających na postępującej integracji porządków prawnych państw członkowskich odegrały agencje regulacyjne Unii Europejskiej (UE). Jest to heterogeniczna grupa instytucji zapewniających wsparcie eksperckie dla organów UE w wyspecjalizowanych sektorach rynku, takich jak bezpieczeństwo żywności, nadzór finansowy, telekomunikacja, obrót lekami czy chemikalia-

${ }^{1}$ Katedra Teorii Stosunków Międzynarodowych, Instytut Prawa Międzynarodowego, Unii Europejskiej i Stosunków Międzynarodowych, Wydział Prawa i Administracji, Uniwersytet Kardynała Stefana Wyszyńskiego w Warszawie.

2 Tekst powstał w ramach projektu badawczego sfinansowanego ze środków Narodowego Centrum Nauki przyznanych na podstawie decyzji numer DEC-2013/09/D/ HS5/01277. 
mi. Głównym celem, który przyświecał pomysłodawcom pierwszych agencji było stworzenie ram instytucjonalnych zapewniających zabezpieczanie unijnego procesu regulacyjnego pod względem fachowych opinii i wytycznych. Organy UE, w tym przede wszystkim Komisja Europejska (KE), nie były w stanie sprostać roli „wyspecjalizowanego prawodawcy” w przypadku wielu złożonych kwestii z różnych dziedzin. 0 ile w odniesieniu do pierwszych agencji z lat $90 \mathrm{XX} \mathrm{w.}{ }^{3}$, które miały przede wszystkim charakter gremiów doradczych, ich rola w procesach tworzenia europejskich aktów normatywnych nie budziła większych kontrowersji, o tyle nowsze instytucje tego typu, powstałe w latach 2000. stały się przedmiotem intensywnej debaty, głównie wśród prawników zajmujących się europejskim prawem administracyjnym ${ }^{4}$. Podstawowy problem, który jest tematem wielu analiz prawnych, to kwestia legitymizacji działań takich agencji, jak np. Europejska Agencja Chemikaliów (ECHA), Agencja ds. Współpracy Organów Regulacji Energetyki (ACER), Europejska Agencja Bezpieczeństwa Lotniczego (EASA), Europejska Agencja Bezpieczeństwa Sieci i Informacji (ENISA) czy Europejski Urząd Nadzoru Bankowego (EBA), których kompetencje wykraczają poza fachową ekspertyzę. Agencje najnowszej generacji uzyskują coraz częściej także uprawnienia decyzyjne czy semiregulacyjne. To znaczy na przykład, że mają prawo wydawać decyzje prawnie wiążące dla podmiotów prywatnych albo że projekty aktów prawnych, na przykład rozporządzeń przez nie przygotowanych są na zasadzie pewnego automatyzmu - często w sposób bezpośredni zagwarantowany w aktach powołujących te agencje do życia - przyjmowane przez $\mathrm{KE}^{5}$.

Takie kompetencje ciągle należą jednak do wyjątkowych i nie one wpływają na długofalowe oddziaływanie agencji regulacyjnych UE na porządki

${ }^{3}$ Np. Europejska Agencja Bezpieczeństwa i Zdrowia w Pracy (EU-OSHA) czy Europejska Agencja Środowiska (EEA).

${ }^{4}$ Zob. np. E. Chiti, The Emergence of a Community Administration: The Case of European Agencies, „Common Market Law Review” 37 (2000), nr 2, s. 309-343; E. Vos, Reforming the European Commission: What Role to Play for EU Agencies?, „Common Market Law Review" 37 (2005), s. 1113-1147; R. Dehousse, Regulation by Networks in the European Community: The Role of European Agencies, „Journal of European Public Policy“ 4 (1997), nr 2, s. 246-261.

${ }^{5}$ Szerzej na ten temat zob. np.: M. Busuioc, Rule-Making by the European Financial Supervisory Authorities: Walking a Tight Rope, „European Law Journal” 19 (2013), nr 1, s. $111-125$. 
:::: Natalia Kohtamäki, Kultura organizacyjna w agencjach regulacyjnych...

prawne państw członkowskich. Zasadniczą rolę w tym zakresie odgrywa tzw. miękkie prawo (ang. soft law), czyli opinie, zalecenia i wytyczne tych instytucji. W znaczny sposób kształtuje ono narodowe regulacje, głównie na zasadzie silnie oddziałującego prestiżu agencji regulacyjnych. Prestiż ten wynika z uznania ich za gremia eksperckie, opracowujące dokumenty wysokiej jakości i zawierające informacje, o których pogłębioną wiedzę ma jedynie wąski krąg wtajemniczonych. Otoczenie agencji regulacyjnych takim szczególnym nimbem tajemnicy, wynikającej z niedostępnej dla laików fachowości jest rezultatem braków, jeśli chodzi o bezpośrednie mechanizmy legitymizacji ich działalności.

Instytucje te powoływane są na podstawie aktów prawa wtórnego i nie mają „bezpośredniego upoważnienia” od obywateli państw członkowskich do wykonywania swoich coraz szerzej ujmowanych przez ustawodawcę unijnego kompetencji. W związku z powyższym stosuje się do tych gremiów utylitarystyczne koncepcje legitymizacji, odwołujące się do rezultatów wynikających z ich działalności. Wedle takich założeń uprawomocnienie systemu politycznego zależy od jego zdolności do osiągania celów ${ }^{6}$. Znaczenie mają zatem korzyści, jakie wnosi fachowa ekspertyza. To efektywność działań i wysoka jakość opracowywanych dokumentów mają legitymizować aktywność agencji regulacyjnych w strukturach administracji unijnej. Szczególne znaczenie dla realizacji takich istotnych z punktu widzenia procesów legitymizacji postulatów skuteczności ma kultura organizacyjna agencji regulacyjnych.

\section{KULTURA ORGANIZACYJNA - ROZUMIENIE POJĘCIA}

Termin „kultura organizacyjna” jest stosowany w różnych kontekstach, w zależności od dyscypliny naukowej i określonej perspektywy badawczej. Zjawiskiem tym zajmują się specjaliści zarówno z zakresu zarządzania, komunikowania i administracji, jak i prawnicy, socjolodzy, psycholodzy czy nawet antropolodzy.

\footnotetext{
${ }^{6}$ Zob. K. Ławniczak, Między demokracją a efektywnością. Trzy spojrzenia na deficyt legitymizacji Unii Europejskiej, „e-Politikon” 2012, nr 3, s. 109.
} 
Kultura organizacyjna powstaje na bazie istniejących w ramach danej organizacji doświadczeń, symboli, wartości, norm i rytuałów. Zawiera się w niej nie tylko dotychczasowa historia danej instytucji, ale też wyobrażenia pracowników ją współkształtujących na temat jej rozwoju i przyszłości. Jest zatem zjawiskiem dynamicznym, zmieniającym się pod wpływem zewnętrznych uwarunkowań, ale i cech związanych z wewnętrzną strukturą każdej instytucji i aktywnością jej pracowników7. Kultura organizacyjna obejmuje tworzone w ramach zbiorowości wzory zachowań, które są kształtowane i modyfikowane wraz ze zdobywaniem wiedzy i nowych doświadczeń. Wzory te wpływają w sposób bezpośredni na rozumienie i interpretowanie rzeczywistości. W związku z tym spełnia ona wiele funkcji ważnych z punktu widzenia istnienia i funkcjonowania każdej organizacji. Po pierwsze, ma działanie stabilizujące, ponieważ przyczynia się do tworzenia pewnych ram orientacyjnych, pozwalających na określenie priorytetów i odnajdywanie właściwych rozwiązań w sytuacjach kryzysowych. Po drugie, pełni funkcję porządkującą, to znaczy sprzyja dokonaniu wyboru istotnych dla organizacji informacji i faktów. I po trzecie, odgrywa ważną rolę $\mathrm{w}$ procesach budowania tożsamości danej organizacji ${ }^{8}$.

W związku z tym analizując kulturę organizacyjną badacze zajmują się takimi wymiarami aktywności w danej organizacji, jak charakter realizowanych przez nią zadań, struktura pracy, obieg informacji, sposoby komunikowania, mechanizmy rozwiązywania problemów, metody nagradzania i sankcjonowania personelu, a także poziom identyfikacji pracowników $\mathrm{z}$ organizacją jako całością ${ }^{9}$ Każda organizacja, w tym także jednostki administracji, kształtuje nie tylko kulturę organizacyjną, ale i wynikające $\mathrm{z}$ niej wizje, dotyczące funkcjonowania w określonych ramach przestrzennych i czasowych.

\footnotetext{
7 Więcej na ten temat zob.: B. Nogalski, A. Szpitter, Kultura organizacyjna $w$ zarzq̨dzaniu organizacjq wielokulturowa, [w:] Historia i perspektywy nauk o zarządzaniu, red. B. Mikuła, Fundacja Uniwersytetu Ekonomicznego, Kraków 2012, s. 225 i n.

${ }^{8}$ Szerzej na ten temat zob. T. Jetzke, Zukunftsforschung und Organisationskultur Organisationskulturelle Zukunftskonzepte als Voraussetzung für die Zukunftsfähigkeit von Organisationen, „Zeitschrift für Zukunftsforschung” 4 (2015), nr 1, s. 35, 38 i n. Na temat tożsamości organizacji zob. też: P. Kocoń, Tożsamość organizacji i kultura organizacyjna - definicje i relacje, „Economics and Management” 1 (2009), nr 1, s. 146 i n.

9 Szerzej na ten temat zob.: A. Wojtowicz, Istota i modele kultury organizacyjnej przegląd koncepcji, „Zeszyty Naukowe” 2004, nr 5, s. 159-171.
} 
:::: Natalia Kohtamäki, Kultura organizacyjna w agencjach regulacyjnych...

W pierwszym przypadku chodzi o interakcje danej instytucji ze środowiskiem, w którym działa. Takie relacje mogą przybierać formę dopasowywania się do istniejącej rzeczywistości czy struktury, w której dana organizacja jest aktywna albo polegać na próbach ich zmian w ramach realizacji własnych interesów i strategii. W przypadku wielu agencji regulacyjnych Unii Europejskiej można mówić o staraniach podejmowanych w celu zmiany sektorów rynku, w których dana instytucja funkcjonuje. Badacze zajmujący się teoriami organizacji piszą w tym kontekście o konstytuującej roli takiego gremium, które aby przetrwać, legitymizować swój byt nie może jedynie trwać w istniejących ramach czy się do nich dopasowywać. Musi podejmować próby współtworzenia środowiska, w którym jest aktywne zgodnie $\mathrm{z}$ własną wizją rozwoju ${ }^{10}$. Jeśli chodzi natomiast o ewolucję czasową organizacji, w literaturze wyróżnia się trzy wymiary: 1) orientację bazującą na przeszłości, czyli istniejących zrutynizowanych regułach postępowania, pewnej tradycji, utartych schematach zachowań; 2) orientację koncentrującą się na teraźniejszości, czyli czynnościach bieżących, aktualnych wzorach aktywności i modelach rozwiązywania sytuacji kryzysowych; 3) orientację obejmującą przyszły rozwój, przy uwzględnieniu zmian środowiska, w którym tkwi dana instytucja ${ }^{11}$.

Kultura organizacyjna, nawiązując do słynnej metafory Geerta Hofstede, jest „zbiorowym zaprogramowaniem umysłu”, na podstawie którego można odróżniać członków poszczególnych grup. To pewien kompleksowy zestaw założeń, który powstaje w danej organizacji w ramach interakcji ze środowiskiem zewnętrznym i w procesach integracji wewnętrznej ${ }^{12}$. Takie zaprogramowanie ewoluuje pod wpływem kultur narodowych, co jest szczególnie widoczne w organizacjach o strukturze wielonarodowej. Instytucje administracji europejskiej są najlepszym przykładem kształtowania szczególnej ponadnarodowej kultury organizacyjnej.

Od lat obserwuje się upolitycznienie stanowisk w organach i instytucjach unijnych. Najlepszym przykładem było obsadzanie dyrekcji gene-

10 Zob. R. Wiltbank, N. Dew, S. Read, S. D. Sarasvathy, What to Do Next? The Case for Non-Predictive Strategy, „Strategic Management Journal” 27 (2006), nr 10, s. 981-998.

11 Zob. T. Jetzke, op.cit., s. 39.

${ }_{12}$ G. Hofstede, G. J. Hofstede, Kultury i organizacje. Zaprogramowanie umysłu, Polskie Wydawnictwo Ekonomiczne, Warszawa 2007, s. 297; B. Nogalski, A. Szpitter, op.cit., s. 227 i 229. 
ralnych KE według klucza narodowego. Praktyki te powoli ewoluowały w kierunku modeli bardziej niezależnej, profesjonalnej administracji. Nawet mocno upolitycznione stanowiska kierownicze w KE z czasem stały się bardziej niezależne od wpływów z poszczególnych państw członkowskich. Znajduje to wyraz w regułach związanych z obsadzaniem gabinetów komisarzy, które wcześniej przypominały narodowe reprezentacje, wysyłane przez ministerstwa spraw zagranicznych bądź proponowane przez poszczególnych komisarzy. Obecnie natomiast zakłada się różnorodną reprezentację narodową, równowagę jeśli chodzi o płeć urzędników i ich wysokie kompetencje związane m.in. z uprzednim doświadczeniem zdobytym w strukturach $\mathrm{UE}^{13}$.

Ciekawą grupą urzędników, biorąc pod uwagę zagadnienia kultury organizacyjnej, są osoby wysyłane przez narodowe organy administracyjne do pracy w KE. Są oni integrowani w ramy administracji unijnej, ale opłacani przez instytucje z państw członkowskich. Po wyznaczonym czasie ich oddelegowania do Brukseli powracają na swoje poprzednie stanowiska w urzędach krajowych. Analizy przeprowadzone przez znanego norweskiego badacza Jarle Trondala, zajmującego się zagadnieniami związanymi z systemem zarządzania w UE, dowodzą że urzędnicy ci w dużo większym stopniu identyfikują się z administracją unijną niż ze swoimi macierzystymi ministerstwami ${ }^{14}$. Potwierdza to ogólną tendencję do kosmopolizacji urzędników unijnych, którzy wraz z objęciem stanowiska w Brukseli wkraczają do elitarnego kręgu „pionierów europeizacji”, polegającej m.in. na harmonizowaniu europejskich porządków prawnych ${ }^{15}$. Odrywają się od struktur narodowych, integrując się w ramach formalnych i nieformalnych sieci eksperckich, w których nawet na szczeblu prywatnym narodowość odgrywa drugoplanową rolę. Kontakty rozwijane są na fundamencie wspólnych zadań i zainteresowań, a nie według klucza narodowego.

\footnotetext{
${ }_{13}$ Zob. D. Curtin, M. Egeberg, Tradition and Innovation: Europe's Accumulated Executive Order, [w:] Towards a New Executive Order in Europe?, red. D. Curtin, M. Egeberg, Routledge, London-New York 2015, s. 5.

${ }^{14}$ Szerzej na ten temat zob. J. Trondal, Governing at the Frontier of the European Commission: The Case of Seconded National Experts, „West European Politics” 29 (2006), nr 1, s. $147-160$.

15 Szerzej na ten temat zob. S. Suvarierol, Everyday Cosmopolitanism in the European Commission, „Journal of European Public Policy” 18 (2011), nr 2, s. 181-200.
} 
:::: Natalia Kohtamäki, Kultura organizacyjna w agencjach regulacyjnych...

Powstaje wówczas silna kultura organizacyjna wyrastająca z cech charakterystycznych dla poszczególnych państw członkowskich, ale stanowiąca nową całość, niezależna od specyfiki narodowej. Wykształcenie takiej kultury zapewnia danej instytucji wysoką efektywność. 0 ile aparat urzędniczy związany na przykład z KE kształtuje tak rozumianą kulturę organizacyjną, o tyle w przypadku agencji regulacyjnych UE trudno mówić o takim zjawisku. Występuje tu raczej „wielokulturowa elastyczność” ${ }^{16}$, zwłaszcza jeśli chodzi o organy decyzyjne agencji regulacyjnych, o czym szczegółowo mowa będzie w dalszych rozważaniach.

Pojęcie kultury organizacyjnej łączy się przede wszystkim z przedsiębiorstwami prywatnymi. W ostatnich latach jednak coraz więcej analiz dotyczy kształtowania się tego zjawiska także w organach administracji publicznej ${ }^{17}$. Zwraca się w tym kontekście uwagę na wpływ kultury organizacyjnej na skuteczność jednostek administracji. Występuje ścisła korelacja między dojrzałością kultury organizacyjnej a efektywnością działań organów administracji w zakresie zaspokajania potrzeb publicznych. Kultura organizacyjna danej jednostki administracyjnej wpływa też na jej wizerunek i odbiór społeczny.

Dla jednostek administracji publicznej, podobnie jak dla innych instytucji, charakterystyczne są obok oficjalnych norm i sformalizowanych zachowań niepisane rytuały i reguły działania. Tym nieformalnym zasadom funkcjonowania organizacji poświęcono wiele studiów, uznając je za elementy kształtujące nieznaną, ukrytą stronę każdej instytucji ${ }^{18}$. Jest ona szczególnie interesująca w przypadku agencji regulacyjnych UE, bo wiąże się z tzw. czynnikiem ludzkim, czyli wpływem szczególnych cech narodo-

16 Zob. R. Kamiński, Kultura organizacyjna sprzyjająca innowacyjności w przedsiębiorstwie, „Zarządzanie Zasobami Ludzkimi” 2002, nr 3-4, s. 50.

17 Zob.: I. Seredocha, Kultura nowego typu w jednostkach administracji samorzadowej jako element skutecznego zarządzania $w$ samorządzie terytorialnym, „Studia i Materiały. Miscellanea Oeconomicae" 17 (2013), nr 1, s. 177-188; K. Szymańska, System zarządzania jakościq determinantna zmian kultury organizacyjnej urzędu administracji samorządowej, „Edukacja Ekonomistów i Menedżerów. Problemy. Innowacje. Projekty” 2012, nr 4 (26), s. 105-120.

${ }_{18}$ Przegląd literatury dotyczącej tej tematyki zob. S. Kühl, Informalität und Organisationskultur. Ein Systematisierungsversuch, „Working Paper” 2010, nr 3, tekst dostępny na stronie: http://www.uni-bielefeld.de/soz/forschung/orgsoz/Informalitat-undOrganisationskultur-Workingpaper-01062010.pdf (dostęp: 12.12.2015). 
wych, charakteryzujących urzędników z państw członkowskich na kształtowanie niezależnych i obiektywnych ekspertyz wykorzystywanych przez KE w procesie regulacyjnym. Nieformalne tło będące ważną częścią składową każdej kultury organizacyjnej jest elementem „uczłowieczającym” bezduszną machinę biurokratyczną. W przypadku instytucji wielonarodowych i wielokulturowych, jakimi są agencje regulacyjne, to właśnie nieformalne reguły i obyczaje dotyczące na przykład stosowania prawnie niewiążących wytycznych i zaleceń czy też skutecznego przepływu informacji między poziomem administracji unijnej i narodowej wzmacniają pozycję tych gremiów i ułatwiają funkcjonowanie. Pod pojęciem nieformalnych zasad należy zatem rozumieć nie swobodną improwizację, ale utarte wzorce zachowań, które choć nie są zakotwiczone w konkretnych normach prawnych, są przez daną organizację przestrzegane i respektowane. Tylko wtedy, gdy dostrzeże się takie procesy „nieformalnego sterowania” daną organizacją można zrozumieć strategie jej działania, jej pozycję na tle innych i oddziaływania w szerszych sieciach współpracy, takich jak złożone związki między organami administracji publicznej. Ten nieformalny wkład do kultury organizacyjnej wynika $z$ banalnego faktu, iż nie wszystkie scenariusze można przewidzieć i w związku z tym nie wszystko można uregulować ${ }^{19}$.

Organizacje działające na szczeblu ponadnarodowym, takie jak agencje regulacyjne muszą sprostać wielu wyzwaniom, dla których nierzadko zapisy sformułowane w rozporządzeniach założycielskich okazują się niewystarczające. Stąd pewien dopuszczony przez państwa członkowskie margines swobody, nierzadko wynikający ze specyfiki dziedziny, w której dana agencja jest aktywna. Takimi szczególnymi obszarami wtajemniczenia są na przykład rynki finansowe, bezpieczeństwo lotnicze czy obrót lekami, gdzie relacje między ponadnarodowymi platformami porozumienia, jakimi są agencje regulacyjne, a odpowiednimi urzędami z państw członkowskich bazują na wieloletniej współpracy i wynikającym z niej zaufaniu. Choć nieformalne zachowania w wielu przypadkach ułatwiają funkcjonowanie organizacji, budzą też wiele zastrzeżeń i stają się w przypadku jednostek administracji unijnej argumentem podkreślającym rozwój tych struktur

${ }^{19}$ Zob. ibidem, s. 3 i n. 
:::: Natalia Kohtamäki, Kultura organizacyjna w agencjach regulacyjnych... 75

w kierunku niekontrolowanej technokracji, złowrogiej eurokracji ${ }^{20}$, która coraz silniej oddziałuje na porządki prawne państw członkowskich, sama funkcjonując w nieuregulowanej, zapewniającej ryzykowną swobodę niszy.

\section{Administracja eUROPEJSKa}

Traktat z Lizbony wprowadził po raz pierwszy oficjalnie do prawa pierwotnego termin administracji europejskiej. Art. 298 ust. 1 Traktatu o funkcjonowaniu Unii Europejskiej (TFUE) stanowi, że „wykonując swoje zadania, instytucje, organy i jednostki organizacyjne Unii korzystają ze wsparcia otwartej, efektywnej i niezależnej administracji europejskiej" ${ }^{21}$. Wśród krytyków celowości pogłębiania integracji europejskiej zapis ten wywołuje duże kontrowersje ${ }^{22}$. Legitymizuje on bowiem procesy rozbudowy aparatu administracyjnego na szczeblu UE. Wbrew fundamentalnej dla rozwoju instytucjonalnego UE zasadzie subsydiarności organizacja ta w ostatnich latach zdaje się wspierać centralizację kompetencji na szczeblu europejskim, przesuwając jednoznacznie równowagę kompetencyjną ze szczebla narodowego w przypadku wielu sektorów rynku wewnętrznego. Przesunięcia delegacyjne między organami UE a ,jednostkami organizacyjnymi”, takimi jak agencje regulacyjne nie mają charakteru zwykłego podziału dotychczas istniejących uprawnień. Pojawiają się bowiem ciągle nowe zadania, które krok po kroku i niejako niepostrzeżenie są centralizowane w strukturach „administracji europejskiej”23.

20 Zob. D. Georgakakis, European Civil Service as a Group: Sociological Notes about the "Eurocrats"' Common Culture, [w:] The European Dimension of Administrative Culture, red. J. Beck, F. Thedieck, Nomos-Verlag, Baden-Baden, s. 283-298.

${ }^{21}$ Por. wersja skonsolidowana Traktatu o funkcjonowaniu Unii Europejskiej (Dz.Urz. UE 2012, C 326/47).

${ }^{22}$ Zob. np. C. A. Gebauer, Rettet Europa von der EU. Wie ein Traum an der Gier nach Macht zerbricht, Finanzbuch Verlag, München 2015, s. 9 i n.

${ }^{23}$ Szerzej na ten temat zob.: N. Kohtamäki, Uprawnienia interwencyjne Europejskiego Urzędu Nadzoru Giełd i Papierów Wartościowych. Glosa do wyroku Trybunału Sprawiedliwości Unii Europejskiej z 22 stycznia 2014 roku w sprawie C-270/12 Zjednoczone Królestwo Wielkiej Brytanii i Irlandii Północnej przeciwko Parlamentowi Europejskiemu i Radzie Unii Europejskiej, „Internetowy Kwartalnik Antymonopolowy i Regulacyjny" 5 (2014), nr 3, s. 116 i n.; eadem, Wpływ kryzysu finansowego na kształtowanie sie tożsamości europejskiej. Przykład procedur decyzyjnych $w$ nadzorczych agencjach regu- 
W komentarzach do art. 298 ust. 1 TFUE zwraca się jednak uwagę na fakt, że rozbudowa administracji europejskiej nie jest celem samym w sobie. Ma ona służyć realizacji zadań powierzonych na zasadzie dobrowolności UE ${ }^{24}$. Kluczową rolę odgrywają $w$ tym procesie instytucje, organy i jednostki organizacyjne. Pod tym ostatnim pojęciem kryją się agencje i urzędy UE. W niektórych wersjach językowych traktatu zostały one wprost nazwane $^{25}$. W polskiej wersji językowej takie rozumienie jest interpretowane z kontekstu. Wymienione w art. 298 ust. 1 TFUE gremia tworzą wraz z urzędami administracyjnymi z państw członkowskich UE administrację europejską. Współpraca administracyjna obu poziomów administrowania wynika wprost z art. 197 TFUE, który stanowi, iż „skuteczne wdrażanie prawa Unii przez państwa członkowskie, mające istotne znaczenie dla prawidłowego funkcjonowania Unii, jest uznawane za sprawę będącą przedmiotem wspólnego zainteresowania"26. Powstają złożone struktury organizacyjne łączące aparat administracyjny KE i systemy państw członkowskich. W tym kontekście pojawia się w literaturze wiele koncepcji teoretycznych tłumaczących charakter i mechanizmy funkcjonowania takich sieci współpracy ${ }^{27}$.

Agencje regulacyjne są, jak wspomniano we wprowadzeniu, gremiami pomocniczymi KE. Swój pierwowzór mają w amerykańskich agencjach regulacyjnych, choć różnią się od nich znacznie ze względu na specyficzne

lacyjnych Unii Europejskiej, [w:] Integracja europejska. Główne obszary badawcze, red. K.A. Wojtaszczyk, J. Tymanowski, P. Stawarz, WDiNP UW, Warszawa 2015, s. 158 i n.

${ }^{24}$ Zob. M. Ruffert, Art. 298 AEUV [EU-Eigenverwaltung], [w:] EUV/AEUV. Das Verfassungsrecht der Europäischen Union mit Europäischer Grundrechtcharta. Kommentar, red. C. Calliess, M. Ruffert, Verlag C.H. Beck, München 2011, s. 2518 i n.

25 Zob. N. Kohtamäki, Rola agencji regulacyjnych $w$ tworzeniu europejskiej kultury administracyjnej na przykładzie unijnej agencji nowego typu - Europejskiego Urzędu Nadzoru Giełd i Papierów Wartościowych, „Ius Novum” 2016, nr 3. Porównanie wersji językowych art. 298 TFUE: A. Nowicka, Równoważność wersji językowej - kilka uwag do artykułu 298 Traktatu o funkcjonowaniu Unii Europejskiej, tekst dostępny: http://www. repozy torium.uni.wroc.pl/Content/40325/009.pdf (dostęp: 12.12.2015), s. 129 i n.

${ }^{26}$ Zob. wersja skonsolidowana Traktatu o funkcjonowaniu Unii Europejskiej (Dz.Urz. UE 2012, C 326/47).

27 Zob. np. M. Ruffert, Europäisiertes allgemeines Verwaltungsrecht im Verwaltungsverbund, „Die Verwaltung” 41 (2008), s. 543 i n.; J.-P. Schneider, Strukturen des europäischen Verwaltungsverbunds. Einleitende Bemerkungen, „Die Verwaltung. Beihefte” 2010, nr 8, s. 9 i n. 
:::: Natalia Kohtamäki, Kultura organizacyjna w agencjach regulacyjnych...

ponadnarodowe środowisko funkcjonowania i zróżnicowany zakres kompetencji przypisany poszczególnym instytucjom. Agencje regulacyjne są samodzielnymi, wyposażonymi w dużą autonomię instytucjonalną jednostkami administracji europejskiej, powoływanymi na podstawie konkretnych rozporządzeń założycielskich, w których szczegółowo uregulowane są ich zadania i zakres działania. Wraz z wprowadzeniem art. 298 ust. 1 TFUE agencje po raz pierwszy zostały dostrzeżone jako element niezależnej struktury administracyjnej na szczeblu ogólnoeuropejskim. Explicite wyrażony postulat niezależności ma w kontekście tych instytucji szczególne znaczenie. Z jednej strony szeroka autonomia instytucjonalna - wyrażająca się w niezależności organizacyjnej, politycznej, prawnej czy finansowej - ma zapewnić możliwie wysoki i obiektywny poziom specjalistycznej ekspertyzy. Z drugiej jednak strony, jak wspomniano wyżej, okryta nimbem tajemniczości technokracja nie budzi zaufania i prowokuje do pytań na temat mechanizmów pociągania do odpowiedzialności instytucji wyposażonych w uprawnienia do tworzenia wpływającego na prawo członkowskie soft law (np. wytyczne i zalecenia wielu agencji) czy uprawnienia decyzyjne w konkretnych przypadkach ${ }^{28}$.

Agencje jako część europejskiej administracji podlegają kontroli ze strony KE, która na podstawie art. 17 ust. 1 zdanie 2 Traktatu o Unii Europejskiej (TUE) „czuwa nad stosowaniem Traktatów i środków przyjmowanych przez instytucje na ich podstawie"29. Ponadto według art. 17 ust. 1 zdanie 5 TUE KE „pełni funkcje koordynacyjne, wykonawcze i zarządzające, zgodnie z warunkami przewidzianymi w Traktatach". W związku z tym uznaje się, że KE jest upoważniona do sprawowania nadzoru prawnego także nad agencjami regulacyjnymi, chociaż nie ma zgodności co do tego czy może kierować do nich konkretne polecenia natury kontrolnej i zarządzającej. Można przyjąć za Matthiasem Ruffertem, że właściwym punktem odniesienia powinny być w tym kontekście rozporządzenia założycielskie, z któ-

${ }^{28}$ Zob. np.: U. Häde, Jenseits der Effizienz: Wer kontrolliert die Kontrolleure? Demokratische Verantwortlichkeit und rechtsstaatliche Kontrolle der europäischen Finanzaufsichtsbehörden, „Europäische Zeitschrift für Wirtschaftsrecht” 22 (2011), nr 17, S. 662-665; T. Groß, Unabhängige EU - Agenturen - eine Gefahr für die Demokratie?, „Juristenzeitung" 67 (2012), nr 22, s. 1087-1093.

${ }_{29}$ Zob. wersja skonsolidowana Traktatu o Unii Europejskiej (Dz.Urz. UE 2010, C 83/13). 
rych należy odczytać, jaka idea przyświecała ustawodawcy unijnemu przy tworzeniu danej agencji. Niektóre z nich, wyposażone w uprawnienia natury monitorującej, doradczej i informacyjnej, podlegają zgodnie z takim założeniem ściślejszemu wpływowi KE. Natomiast agencje, którym wprost zagwarantowano duży zakres samodzielności i własne uprawnienia semiregulacyjne i decyzyjne mają także większą swobodę działania w stosunku do mechanizmów nadzorczych $\mathrm{KE}^{30}$.

Nasuwa się zatem myśl, jaką rolę może w takich sytuacjach odegrać kultura organizacyjna. Nie ulega wątpliwości, że w przypadku kształtowania roli KE jako „kontrolera” jednostek administracji europejskiej duże znaczenie mają niepisane reguły, zwyczaj i wzajemne zaufanie między poszczególnymi ogniwami tego systemu. Stanowią one ważny filar niesformalizowanej europejskiej kultury organizacyjnej. Może to stać w sprzeczności z postulatem „otwartej administracji” sformułowanym w przywoływanym art. 298 ust. 1 TFUE i art. 15 TFUE. Ponownie zatem pojawia się dylemat wyboru pomiędzy skutecznością działania takich gremiów a spełnianiem przez nie warunków określonych w prawie pierwotnym. Art. 298 ust. 1 TFUE gwarantuje, że administracja europejska ma być nie tylko otwarta, ale też efektywna i niezależna. Odpowiada to prawu obywateli UE do „dobrej administracji", które zostało sformułowane w art. 41 Karty Praw Podstawowych $^{31}$. Zatem zapis z art. 298 ust. 1 TFUE odgrywa w tym kontekście ważną rolę, ponieważ wyodrębnia niezależną administrację unijną, realizując ideę podziału władzy. Pomysł ten trafił do projektów zmian prawa pierwotnego z inicjatywy państw skandynawskich, w tym zwłaszcza Szwecji, którym zależało na kształtowaniu w ramach UE „dobrej kultury administracyjnej"32.

\footnotetext{
30 Zob. M. Ruffert, Art. 298 AEUV, s. 2521.

31 Zob. Karta Praw Podstawowych (Dz.Urz. UE 2012, C 326/391).

32 Szerzej na ten temat zob. K. Michel, Institutionelles Gleichgewicht und EU - Agenturen. Eine Analyse unter besonderer Berücksichtigung der European Banking Authority, Duncker \& Humblot, Berlin 2015, s. 45.
} 
:::: Natalia Kohtamäki, Kultura organizacyjna w agencjach regulacyjnych...

\section{SpecyficzNe uWARUNKowaNia dLA KSZTAtTOWANIA KULTURY ORGANIZACYJNEJ AGENCJI REGULACYJNYCH UE}

W związku ze zmianami, jakie zaszły w prawie pierwotnym, a także z działaniami KE, Parlamentu i Rady ${ }^{33}$ na rzecz ujednolicenia pozycji agencji regulacyjnych w unijnym systemie instytucjonalnym budzą one w ostatnich latach w literaturze prawniczej i politologicznej rosnące zainteresowanie. W badaniach na ich temat przodują ośrodki niemieckie, holenderskie, brytyjskie i skandynawskie ${ }^{34}$. W centrum zainteresowania są przede wszystkim ramy prawne regulujące powstawanie i funkcjonowanie tych gremiów, z naciskiem na niezależność agencji i mechanizmy kontrolne w stosunku do ich działań. Dużo mniej uwagi poświęca się celowości tworzenia tych instytucji, a także mechanizmom wpływającym na realizację zagwarantowanego w prawie pierwotnym postulatu dobrej, czyli m.in. także efektywnej administracji. Dla jego urzeczywistnienia znaczenie ma dojrzała kultura organizacyjna i związane z nią procesy socjalizacji kadr urzędniczych na szczeblach ponadnarodowych.

Jak wspomniano wyżej agencje regulacyjne są szczególnymi jednostkami administracji unijnej. Wynika to m.in. z ich struktury organizacyjnej. W jej skład wchodzi zazwyczaj dyrektor wykonawczy, zarząd, w którym prawo głosu mają najczęściej urzędnicy wysokiego szczebla z państw członkowskich, doradcze komitety naukowe i techniczne, a także, jak w przypadku agencji nadzoru finansowego, grupy interesariuszy. Oprócz kadry zarządzającej agencje dysponują zróżnicowanym liczebnie personelem. Największe agencje, takie jak ECHA, EASA, Europejska Agencja Zarządzania Współpracą Operacyjną na Zewnętrznych Granicach Państw Członkowskich Unii Europejskiej (FRONTEX) czy Urząd UE ds. Własności Intelektualnej (EUIPO) mają nawet kilkuset pracowników. Są oni rekru-

33 Obszernie na temat kroków podejmowanych w tym kierunku: http://europa.eu/ about-eu/agencies/overhaul/index_pl.htm (dostęp: 12.12.2015).

${ }^{34}$ M.in. ośrodek norweski: Arena Centre for European Studies, ośrodek holenderski: Amsterdam Centre for European Law and Governance czy ośrodek brytyjski (przy London School of Economics): Centre for Analysis of Risk and Regulation, a także wiele niemieckich ośrodków uniwersyteckich (zob. np. analizy poświęcone agencjom regulacyjnym przygotowane przez badaczy z uniwersytetów w Bonn, Jenie czy Frankfurcie nad Menem). 
towani z złożonych, wieloetapowych procesach i zatrudniani na czas nieokreślony bądź czasowo, na przykład w związku z realizacją konkretnego projektu. Ten agencyjny personel urzędniczy podziela cechy pracowników z innych instytucji unijnych. To znaczy definiuje swoje zatrudnienie w kategoriach ponadnarodowych, realizując ideę „pracy dla Europy”, która stanowi rdzeń rozwijającej się od kilkudziesięciu lat najpierw w ramach Wspólnot, a obecnie w strukturach UE „europejskiej kultury korporacyjnej” ${ }^{35}$.

Tak jak już wyjaśniono w części poświęconej rozumieniu pojęcia kultury organizacyjnej, znaczna część pracowników administracji europejskiej identyfikuje się z systemem instytucjonalnym UE. Dochodzi do oderwania od „zaplecza narodowego”. Brukselska kadra urzędnicza wykształca specyficzne ponadnarodowe poczucie wspólnoty oraz wolę realizacji celów i interesów Unii jako całości. Przy czym warto zauważyć, że stopień identyfikacji konkretnego urzędnika ze strukturami unijnymi zależy od wielu czynników. W badaniach socjologicznych bierze się pod uwagę jego wcześniejsze doświadczenia w sektorze prywatnym i publicznym, w organizacjach krajowych i międzynarodowych, zajmowane w administracji unijnej stanowisko czy charakter zatrudnienia (czasowe lub stałe) ${ }^{36}$.

Mimo pewnych tendencji wspólnych dla różnych jednostek administracji unijnej agencje regulacyjne wykształciły szczególną kulturę organizacyjną. Jej specyfika wynika ze struktury zatrudnienia: duża część pracowników zatrudniona jest na czas określony ${ }^{37}$, a gremia decyzyjne składają się z urzędników delegowanych kilka razy w roku na zebrania zarządów. Podstawowy zamysł, który tłumaczy taki typ zatrudnienia wiąże się z charakterem agencji. Powstały one jako gremia specjalistyczne, w związku z tym ich pracownicy to w przeważającej mierze wyspecjalizowani w wąskiej dyscyplinie eksperci ze szczebla narodowego, którzy z reguły nie planują kariery urzędniczej w instytucjach unijnych. Przyczyniają się oni niewątpliwie

35 Zob. S. Suvarierol, M. Busuioc, M. Groenleer, Working for Europe? Socialization in the European Commission and Agencies of the European Union, „Public Administration" 91 (2013), nr 4, s. 909.

${ }^{36}$ Ibidem, s. 911.

$37 \mathrm{~W}$ ponad 30 agencjach regulacyjnych zatrudnionych jest na czas określony ok. 3000 urzędników, natomiast ok. 600 na czas nieokreślony. Zob. A. Schout, F. Pereyra, The Institutionalization of EU Agencies: Agencies as „,Mini Commissions”, „Public Administration" 89 (2011), nr 2, s. 426. 
:::: Natalia Kohtamäki, Kultura organizacyjna w agencjach regulacyjnych...

poprzez kształtowanie szczególnej administracyjnej kultury organizacyjnej do zacieśniania związków pomiędzy obydwoma poziomami administrowania. Ponadto agencje to instytucje peryferyjne w wielu znaczeniach tego słowa. To znaczy z jednej strony są rozproszone w różnych państwach członkowskich i nie mają ścisłych związków instytucjonalnych z Brukse$\mathrm{lą}^{38}$. Z drugiej strony są peryferyjne także pod względem ich znaczenia. Mają charakter pomocniczy i choć zajmują się zagadnieniami o żywotnym znaczeniu dla Unii jako całości i dla poszczególnych państw członkowskich, to najczęściej ze względu na wysoki poziom specjalizacji ich problematyka nie znajduje zainteresowania mediów i tym samym szerszej opinii publicznej.

Chociaż agencjom regulacyjnym poświęca się w powszechnym odbiorze niewiele uwagi, to wzbudzają one dużo emocji ze strony państw członkowskich, szczególnie w okresie ich tworzenia. Obok rywalizacji o ustanowienie siedziby takich gremiów na swoim terytorium, państwa z dużym zaangażowaniem, zwłaszcza $\mathrm{w}$ przypadku silnych agencji, negocjują postanowienia zawarte $\mathrm{w}$ rozporządzeniach założycielskich. Chodzi przede wszystkim o ograniczanie uprawnień konkurencyjnych do kompetencji organów narodowych, a także unikanie rozwiązań, w stosunku do których państwa członkowskie nie mogą osiągnąć kompromisu ${ }^{39}$. Tego typu oddziaływania znajdują następnie odzwierciedlenie w debatach wewnątrz agencyjnych zarządów. W ich skład wchodzą szefowie narodowych urzędów regulacyjnych z danego sektora, a także reprezentanci organów UE (przede wszystkim Komisji) i innych instytucji. Prawo głosu przysługuje z reguły urzędnikom z państw członkowskich, którzy nierzadko budują koalicje na rzecz realizacji interesów narodowych.

Zarządy ze względu na swój złożony, wielonarodowy charakter i dużą liczebność, która może sięgać nawet kilkudziesięciu osób kształtują specyficzną agencyjną kulturę organizacyjną. Jej oryginalność wynika z faktu niewielkiej identyfikacji członków zarządu z samą agencją. Uczestniczą oni zaledwie kilka razy w roku w obradach, na które nierzadko przybywają nie-

38 Odległość geograficzna od centrali uważana jest za argument na rzecz gwarantowania niezależności instytucjom administracji publicznej. Szerzej także w kontekście agencji regulacyjnych UE: M. Egeberg, J. Trondal, Agencification and Location: Does Agency Site Matter?, „Public Organization Review“ 11 (2011), nr 2, s. 99.

${ }^{39}$ Zob. A. Schout, F. Pereyra, op.cit., s. 421. 
przygotowani. Udział w spotkaniach zarządu jest ich dodatkowym obowiązkiem w stosunku do zadań realizowanych w narodowych ministerstwach i agencjach. Nieprzygotowanie może więc wynikać z braku zainteresowania konkretnego urzędnika sprawami agencji, ale także niewystarczających przepływów informacji między szczeblami administracji unijnej i narodowej. Badania empiryczne w wybranych agencjach dowodzą, że zwłaszcza reprezentanci państw małych i średnich z Europy Środkowej i Wschodniej, które przystępowały do UE od 2004 r., nie wykazują zaangażowania w sprawy agencji, co wyraża się m.in. w milczącym udziale w obradach zarządu ${ }^{40}$.

Natomiast pierwszoplanową rolę odgrywają $\mathrm{w}$ nich przedstawiciele KE, którzy mają specjalny status, wyraża się on m.in. tym, że w sposób nieformalny kontrolują przygotowania i same spotkania tych gremiów decyzyjnych agencji. $\mathrm{W}$ wielu agencjach zasiadają wraz z dyrektorem wykonawczym na czele obrad zarządów. Decyzje podczas spotkań zarządów zapadają w wielu agencjach na zasadzie konsensusu. Tylko w przypadku najważniejszych decyzji, takich jak wybór dyrektora wykonawczego albo gdy nie uda się wypracować porozumienia, wdrażane są formalne procedury głosowania zgodnie z zapisami rozporządzeń założycielskich. Takie rozwiązanie jest typowe dla agencji o charakterze informacyjnym i doradczym. Natomiast agencje o kompetencjach semiregulacyjnych, decyzyjnych czy operacyjnych regularnie stosują procedury głosowania i tym samym zachowują większą niezależność od KE, której reprezentant w agencjach informacyjnych bierze aktywny udział w osiąganiu konsensusu. Nierzadko obrady zarządu są poprzedzane spotkaniami w mniejszym gronie, które służą właśnie wypracowaniu porozumienia w najbardziej złożonych kwestiach, a także przygotowaniu rozwiązań, które w wielu przypadkach są potem jedynie potwierdzane na przykład $\mathrm{w}$ drodze głosowania. Te $\mathrm{w}$ wielu agencjach wiążą się z budowaniem koalicji państw wspierających się wzajemnie i lobbujących za konkretną sprawą. Co istotne, także w takich koalicjach, KE jako główny „nadzorca” europejskich urzędów regulacyjnych odgrywa decydującą rolę ${ }^{41}$.

${ }^{40}$ N. Font, Informal Rules and Institutional Balances on the Boards of EU Agencies, "Administration \& Society“ 2015, artykuł dostępny w wersji online opublikowanej w czerwcu 2015 r., s. 17.

${ }^{41}$ Ibidem, s. 10 i 16. 
:::: Natalia Kohtamäki, Kultura organizacyjna w agencjach regulacyjnych...

Na czele agencji stoją wspomniani dyrektorzy wykonawczy, którzy stają się niejako „twarzą" tych instytucji, reprezentują je na zewnątrz i koordynują ich pracę. Nie ulega wątpliwości, że od osobowości dyrektora, jego charyzmy i wizji w dużej mierze zależy pozycja agencji regulacyjnej w europejskim, wielopoziomowym systemie administracyjnym. W niektórych studiach poświęconych pracy agencji zauważa się, że pole manewru pozostawione dyrektorom wykonawczym w rozporządzeniach założycielskich może być mocno ograniczone na rzecz silnego wpływu KE. Tak, jak w przypadku ewolucji roli Europejskiej Agencji Środowiska (EEA), w której pierwszy dyrektor borykał się z dużymi problemami, gdy starał się wzmacniać niezależną pozycję tej instytucji w stosunku do $\mathrm{KE}^{42}$.

Agencje regulacyjne różnią się między sobą nie tylko pod względem przypisanych kompetencji. Mimo pewnych elementów zbieżnych, o czym była mowa powyżej, ich kultury organizacyjne nie rozwijają się w identyczny sposób. Różnice wynikają ze specyfiki każdej agencji. Duże kilkusetosobowe instytucje funkcjonują inaczej niż mniejsze kilkudziesięcioosobowe agencje. Największe z nich posiadają rozbudowane zaplecze w postaci restauracji czy sal sportowych. Umożliwiają też swoim pracownikom nawiązywanie kontaktów towarzyskich, czemu służyć mają duże spotkania integracyjne, na przykład z okazji świąt narodowych ${ }^{43}$. Tego typu inicjatywy kształtują wspólną tożsamość danej organizacji i stanowią ważny fundament dla dojrzałej kultury organizacyjnej. Agencje różnią się też pod względem struktury wiekowej pracowników. Niektóre, takie jak np. Europejska Agencja ds. Leków (EMA), stawiają na młodych, licząc na ich szybką asymilację w ramach organizacji i sprawne zdobycie potrzebnych umiejętności ${ }^{44}$. Inne agencje, jak np. ECHA czy FRONTEX podkreślają w procesie rekruta-

${ }^{42}$ A. Schout, F. Pereyra, op.cit., s. 424.

${ }_{43}$ Zob. wyniki ankiet przeprowadzonych wśród pracowników agencji w: S. Suvarierol, M. Busuioc, M. Groenleer, op.cit., s. 918.

${ }^{44}$ Chociaż należy w tym miejscu dokonać rozróżnienia między pracownikami wykonującymi zadania natury administracyjnej i tymi, którzy muszą posiadać obszerną wiedzę i doświadczenie. Zob. np. trwające procedury rekrutacyjne w EMA na stanowiska asystenta administracyjnego (księgowość) i specjalisty z zakresu toksykologii (Job references: EMA/AST/390 i EMA/AD/388): http://www.ema.europa.eu/ema/index. jsp?curl=pages/about_us/general/general_content_000325.jsp (dostęp: 12.12.2015). 
cyjnym konieczność posiadania wystarczającego, najczęściej minimum kilkuletniego doświadczenia na podobnym stanowisku ${ }^{45}$.

Dla odmiennej kultury organizacyjnej w poszczególnych agencjach regulacyjnych UE nie bez znaczenia jest też aspekt związany z ich rozproszeniem geograficznym. Aktualnie istnieje 35 instytucji tego typu, z których każda ma siedzibę w innym mieście, w różnych państwach członkowskich. Geograficzna decentralizacja była zamierzona i oznaczała zwiększenie niezależności instytucjonalnej agencji od KE. Z praktycznego punktu widzenia takie rozbicie struktury administracyjnej ma jednak wiele wad. Jedną z nich są trudności w kształtowaniu spójnej kultury organizacyjnej. Według badań empirycznych usytuowanie różnych podmiotów należących do tej samej struktury w jednym mieście lub w niewielkiej odległości od siebie znacznie poprawia wymianę informacji między nimi, ułatwia koordynację ich działań i przyczynia się do intensywniejszego kształtowania wzajemnych powiązań. Pomimo rozwoju nowoczesnych technologii i sposobów komunikowania ciągle jeszcze kontakty bezpośrednie są oceniane jako najbardziej wartościowe, jeśli chodzi o przepływ danych i synchronizację działań w ramach różnych organizacji ${ }^{46}$.

Ponadto znaczenie ma również wielość interesów reprezentowanych w agencjach regulacyjnych. Nie są one „monolitem” jak większość organizacji prywatnych czy jednostek administracji publicznej w państwowych systemach administracyjnych. Stanowią mozaikę interesów i kultur administracyjnych poszczególnych państw członkowskich. Mimo wielu wspólnych regulacji w tak żywotnych sektorach rynku jak nadzór bankowy czy bezpieczeństwo morskie, państwa intensywnie lobbują na rzecz utrzymania własnych szczegółowych rozwiązań normatywnych, często wynikających z tradycji i chroniących rodzime podmioty ${ }^{47}$. Mimo ideału działania „na rzecz Europy”, „,w imię wspólnych celów” czy „dla Unii jako całości” pań-

\footnotetext{
${ }^{45}$ Zob. FRONTEX: http://frontex.europa.eu/about-frontex/job-opportunities/job-opportunities/ (dostęp: 12.12.2015) i ECHA: http://echa.europa.eu/about-us/jobs/ open-positions (dostęp: 12.12.2015).

${ }_{46}$ Wskazuje na to ok. 70\% ankietowanych w ramach badań zarówno na szczeblu krajowym, jak i unijnym. Por. M. Egeberg, J. Trondal, op.cit., s. 99 i n.

47 Zob. E. M. Heims, Explaining Coordination Between National Regulators in EU Agencies: The Role of Formal and Informal Social Organization, „Public Administration” 2015, artykuł dostępny w wersji online opublikowanej w listopadzie 2015 r., s. 5.
} 
:::: Natalia Kohtamäki, Kultura organizacyjna w agencjach regulacyjnych...

stwa w poszczególnych agencjach, głównie w ramach aktywności swoich bezpośrednich przedstawicieli w agencyjnych zarządach starają się realizować własne cele i interesy. Aktywność urzędów regulacyjnych na szczeblu unijnym jest nierzadko odbierana przez instytucje krajowe krytycznie i z dużą ostrożnością. Często organizacje te są postrzegane jako zbędna biurokracja, która przyczynia się do mnożenia dodatkowych obowiązków dla urzędników z państw członkowskich i może stanowić zagrożenie dla organów administracji krajowej. Znaczenie ma zatem profesjonalizm ekspertów delegowanych do pracy w grupach roboczych agencji regulacyjnych, ponieważ to od ich zaangażowania, przygotowania merytorycznego i umiejętności perswazyjnych zależy powodzenie w forsowaniu własnych rozwiązań na szczeblu unijnym ${ }^{48}$.

Mimo różnic pomiędzy poszczególnymi agencjami regulacyjnymi starają się one tworzyć sieć współpracujących ze sobą urzędów (ang. Network of EU Decentralised Agencies). Wypracowaniu wspólnych praktyk, także jeśli chodzi o kulturę organizacyjną, mają służyć spotkania dyrektorów wykonawczych koordynowane przez rotacyjnie zmieniające się agencje. Utworzenie takiej sieci wspierających się instytucji ma na celu wzmocnienie pozycji agencji w europejskiej przestrzeni administracyjnej, promowanie dobrego zarządzania i lepszą realizację wspólnego dla tych gremiów mandatu, tj. działania jako wysoko wyspecjalizowane instytucje eksperckie. Te postulaty ma odzwierciedlać ukute w ramach sieci hasło: „cokolwiek robisz, pracujemy dla ciebie" (ang. Whatever you do, we work for you) ${ }^{49}$.

\section{Podsumowanie}

Agencje regulacyjne UE stały się trwałym elementem europejskiej sieci administracyjnej. Funkcjonują w ramach ścisłej współpracy z odpowiednimi

\footnotetext{
${ }^{48}$ Zob. wywiady z urzędnikami z wybranych urzędów regulacyjnych państw członkowskich, ibidem, s. 9 i n.

${ }^{49}$ W zarządzaniu współpracą w ramach sieci bierze udział tzw. trojka, czyli trzy agencje: poprzedni, obecny i przyszły koordynator prac. Aktualna trojka to: Europejska Fundacja na rzecz Poprawy Warunków Życia i Pracy - Eurofound (2015), Urząd UE ds. Własności Intelektualnej - EUIPO (2016) i Europejski Urząd ds. Bezpieczeństwa Żywności - EFSA (2017). Zob. https://www.eurofound.europa.eu/de/eurofound-coordinating-the-network-of-eu-decentralised-agencies-2015 (dostęp: 2.3.2016).
} 
urzędami z państw członkowskich. Wieloletni rozwój mechanizmów kooperacyjnych między poziomem unijnym a narodowym doprowadził do ich daleko idącej instytucjonalizacji. Niezależnie od tego czy dana agencja pełni przede wszystkim funkcje doradcze i informacyjne, czy ma uprawnienia quasi-prawodawcze i decyzyjne, stanowi z reguły ważną platformę koordynacyjną, jeśli chodzi o kontakty podmiotów z 28 państw członkowskich regulujących konkretny segment rynku wewnętrznego. Tworzenie agencji należy widzieć w szerszej perspektywie rozwijania różnych form współpracy w dynamicznie integrującej się Europie. Stopniowe zacieśnienie obszarów współdziałania oznacza konieczność poszukiwania nowych form współpracy międzyrządowej. Należy je odróżnić od struktur ponadnarodowych czy transnarodowych. Takie rozróżnienie ma praktyczne skutki, jeśli chodzi o procesy kształtowania kultury organizacyjnej w analizowanych instytucjach.

Formalne i nieformalne reguły, wzory, symbole, rytuały, tradycje i zwyczaje rozwijane w organizacjach ponadnarodowych są w dużo większym stopniu internalizowane. Pracownicy poszczególnych dyrekcji KE częściej niż pracownicy agencji uznają kształtowane w ramach UE systemy wartości za własne. Postrzegają swoje obowiązki w kontekście powodzenia całej Unii. Badania psychologiczne i socjologiczne dowodzą, że to w ich przypadku zachodzą procesy tzw. socjalizacji, czyli nabywania norm i wzorów zachowań powstających w ramach ponadnarodowych ${ }^{50}$.

Agencje regulacyjne są natomiast instytucjami międzyrządowymi. Mimo starań ze strony KE w organach decyzyjnych agencji rzadko dochodzi do utożsamienia się narodowych reprezentantów z agendą ogólnounijną. Nawet stały agencyjny aparat urzędniczy z dyrektorem wykonawczym na czele, choć w mniejszym stopniu niż na przykład delegowani na obrady zarządu narodowi urzędnicy, postrzega swoją rolę raczej jako obiektywnych i niezależnych ekspertów niż jako „unijnych funkcjonariuszy”, jak ma to miejsce w przypadku pracowników dyrekcji KE. Wpływa to na specyficzną kulturę organizacyjną w agencjach regulacyjnych. Stanowi ona kompilację narodo-

50 Szerzej o socjalizacji w kontekście aparatu urzędniczego Komisji Europejskiej: M. Bauer, Tolerant, If Personal Goals Remain Unharmed: Explaining Supranational Bureaucrats' Attitudes to Organizational Change, „Governance” 25 (2012), nr 3, s. 491 i n. 
:::: Natalia Kohtamäki, Kultura organizacyjna w agencjach regulacyjnych...

wych przyzwyczajeń i priorytetów. W tym kontekście trudno więc mówić o spójnym „zaprogramowaniu umysłów”, charakterystycznym na przykład dla wielonarodowych, aktywnych transgranicznie korporacji. Agencje regulacyjne często z tych właśnie powodów nie są w stanie stworzyć kompleksowej wizji swojego istnienia i rozwoju w strukturach unijnych.

Narodowi urzędnicy reprezentują cele, zamierzenia i interesy definiowane w różnorodny sposób, często w zależności od uwarunkowań politycznych w krajach pochodzenia. Zmieniające się koalicje rządzące inaczej rozkładają akcenty, jeśli chodzi o forsowanie konkretnych rozwiązań w poszczególnych dziedzinach. Przedstawiciele KE, odgrywający w agencyjnych gremiach decyzyjnych ważną rolę, widzą działania europejskich urzędów regulacyjnych w szerszej perspektywie, ale także wspierają najczęściej działania istotne z punktu widzenia bieżącej polityki unijnej. Rzadko kiedy, w ramach samych agencji, stawiane są pytania o sens i celowość ich istnienia w dalszej przyszłości. Wizje długookresowe w zasadzie nie istnieją. Trudno je zresztą budować, gdy koncepcje dotyczące kształtu europejskich struktur administracyjnych potrafią ewoluować z roku na rok, czego najlepszym przykładem może być reformowanie europejskiego nadzoru finansowego i zmieniająca się w związku z tym rola Europejskiego Urzędu Nadzoru Bankowego. Mimo to agencje regulacyjne mają potencjał, aby stać się ważnym ogniwem w procesach rozwoju europejskiej kultury administracyjnej, której nieodłączną część stanowi dojrzała kultura organizacyjna.

\section{Natalia Kohtamäkı \\ Organizational Culture in the EU Regulatory Agencies}

Organizational culture means a set of values, norms, symbols, customs and traditions. In consequence it affects the interpretation of reality by employees of the organization, their behavior and impact in relation to other entities. It is also an important foundation in the process of building institutional identity. The problematic of organizational culture is a field of interest for specialists representing many different scientific disciplines. Especially private organizations, such as multicultural, transnational and transboundary active corporations undergone 
multiple detailed analysis both in international and in Polish context. The organizational culture of the EU regulatory agencies, by contrast, has not been analyzed yet in-depth. The article aims to explain the most important problems connected with this topic with special emphasis on the inter-governmental structure of these bodies. 